\title{
FYSIK OG MUSEUM: HAUCHS PHYSISKE CABINET
}

\author{
Hemming Andersen
}

Adam Wilhelm Hauch, der levede 1755-1838, var overhofmarskal hos Frederik VI, og var en markant personlighed, der havde mange administrative og kulturelle hverv $i$ København. Et af disse var udflytningen af Kunstkammeret, som han blev inspirator til og organisator af $i$ begyndelsen af 1800-ärene. ${ }^{1}$ Men allerede $i$ slutningen af 1700arrene havde han skabt sin egen samling affysik-og kemiinstrumenter, som var en af de betydeligste i Europa; man sagde den tredjestørste. Hovedparten af de instrumenter, som udgjorde samlingen findes stadig i god behold på Sorø Akademi og har vundet international anerkendelse som et af de betydeligste bevarede 'physiske Cabinetter' fra Oplysningstiden.

Den historiske forudsætning for physiske Cabinetter skal søges tilbage i begyndelsen af det 17 århundrede, som anses for at være det tidspunkt, hvor vor tids tradition for at eksperimentere blev et grundlag for forskning. Lige siden antikken havde naturens opførsel været et anliggende for filosofiske spekulationer. For eksempel var den traditionelle opfattelse af det skrå kast fra Aristoteles' tid den, at et legeme, der kastedes skråt opad, faldt lodret ned efter at have nået den største højde. Denne teori lå endnu til grund for skydning med kanoner i 1500-årene. ${ }^{2}$ Man kan ikke forestille sig, at en sådan antagelse kan være baseret på omhyggelige observationer.

Man angiver ofte Francis Bacon (15511626) som værende den, der formulerede grundloven for den eksperimentelle undersøgelse af naturen ved hjælp af apparatur.
Han skrev i Novum Organum (1620), at man ikke opnår meget med den nøgne hånd eller med tanken alene, men at undersøgelser fremmes ved hjælp af instrumenter og at disse er 'lige så nødvendige for forståelsen som for hånden'. Ville man lære naturen at kende, måtte man konstruere apparater, ved hjælp af hvilke man kunne aflure naturen dens spilleregler. De kaldtes senere fysikinstrumenter.

Denne udforskning af naturen fremmedes af det løbende samspil mellem konstruktion af instrumenter og opdagelser. Instrumenter blev ikke blot hjælpemidler for naturgranskerne, de blev en integreret part i selve udviklingen. Galilæis formulering af faldlovene inspirerede til fremstilling af skråplaner, som ved selve deres idegrundlag førte til forklaring af de simple 
maskinelementer som kilen, skruen og vægtarmen, samt af kasteapparater og kraner. Da Galilæi i 1609 udnyttede den hollandske opfindelse af kikkerten, indførtes optikken ved siden af mekanikken $\mathrm{i}$ den eksperimentelle fysik. I løbet af 1700-årene diskuteredes om varme var et særligt stof; og den moderne kemi blev bragt til verden af franskmanden Lavoisier. Endelig var der den forunderlige verden, som den nye kraft, elektriciteten, lod ane forude. Det abstraktionsniveau, som behøvedes for at forstå noget af alt det nye, der kom frem om naturen og dens love, var næppe højere, end at mennesker med jævn god intelligens kunne være med, i særdeleshed hvis fænomenerne forklaredes ved illustrerende eksperimenter.

I England udbredtes kendskabet til naturvidenskab i 1700-årene blandt andet af omrejsende foredragsholdere, der informerede jævne folk. ${ }^{3}$ De medbragte ofte en omfattende bagage af demonstrationsapparater, som var opfundet og fremstillet af dem selv. En sådan folkeoplysning kom først til Danmark efter 1824, da Ørsted skabte Selskabet til Naturlerens Udbredelse, - stadig aktiv under betegnelsen SNU.

Men i frontlinien lå selskaber af mænd, der fandt sammen $\mathrm{i}$ en fælles interesse for at udforske naturen. På denne måde opstod societies, der som regel ikke var knyttet til noget universitet, men som var hjernetruster, hvor ideer fostredes, planer for projekter udgik, og som sørgede for at opnåede resultater kom på tryk og blev distribueret. Disse mænd betegnes umiddelbart selvmodsigende, men ganske træffende - amateurs eller savants.

Imellem de to yderområder, folkeoplysningen og forskningscentret for at bruge moderne terminologi, lå oplysningstidens fysiske kabinetter. At de fik denne betegnelse skyldes formentlig, at de spæde begyndelser til apparatsamlinger opbevaredes i skabe (cabinets), og når de blev mere omfattende $\mathrm{i}$ en stue i store boliger, altså hos overklassen. Betegnelsen kabinet for en fin stue kender vi jo.

Disse fysiske kabinetter placerede sig i størrelse og betydning et eller andet sted i området mellem folkeoplysningens niveau og de videnskabelige selskaber og akademier. Nogle har været små og anskaffet for underholdning eller som statussymbol, nogle har været en personlig signet, som når en skibsreder udstyrede sit kontor med globus, sekstant og kompas, som det kan ses på gamle portrætmalerier.

Men nogle var omfattende laboratorier, hvor der blev forsket på højt plan. Hauch indgår ikke $\mathrm{i}$ historien med nogen epokegørende opdagelse, men han var kendt i Europa for sin deltagelse i den videnskabelige debat. $\mathrm{Og}$ til grund for hans argumentering lå altid observationer fra forsøg, som han selv havde gjort i sit laboratorium.

For eksempel deltog han i diskussionen om vands sammensætning, og da en professor i Bonn havde påstået at vand ved kraftig opvarmning kunne blive til kvælstof, opfandt Hauch et slags destillationsapparat, som han lod fremstille i sølv. Med dette gennemførte han en række systematiske forsøg, udført med stor akkuratesse og fandt ingen spor af kvælstof. I en afhandling over forsøgene til Videnskaberne Selskab er han usædvanlig skarp i sin fordømmelse af professorens påstand. ${ }^{4}$

Men han kunne også beskæftige sig med egentlig instrumentkonstruktion. Til eksperimenter med elektricitet opfandt Hauch et udlade-elektrometer, som han 
Fysik og MUSEum: Hauchs physiske Cabinet

Adam Wilhelm Hauch, 1755-1838, overhofmarskal hos Frederik VI og ansvarlig for opdelingen og udflytningen af Kunstkammeret (se Mogens Bencard: Museerne og verdensordenen, Nordisk Museologi 1993:1). Skabte til videnskabelig brug en stor samling af scientiske instrumenter, som nu findes som "Hauchs Physiske Cabinets på Soro Akademi.

Maleri af C. A. Jensen, Videnskabernes Selskab, Kobenhavn.

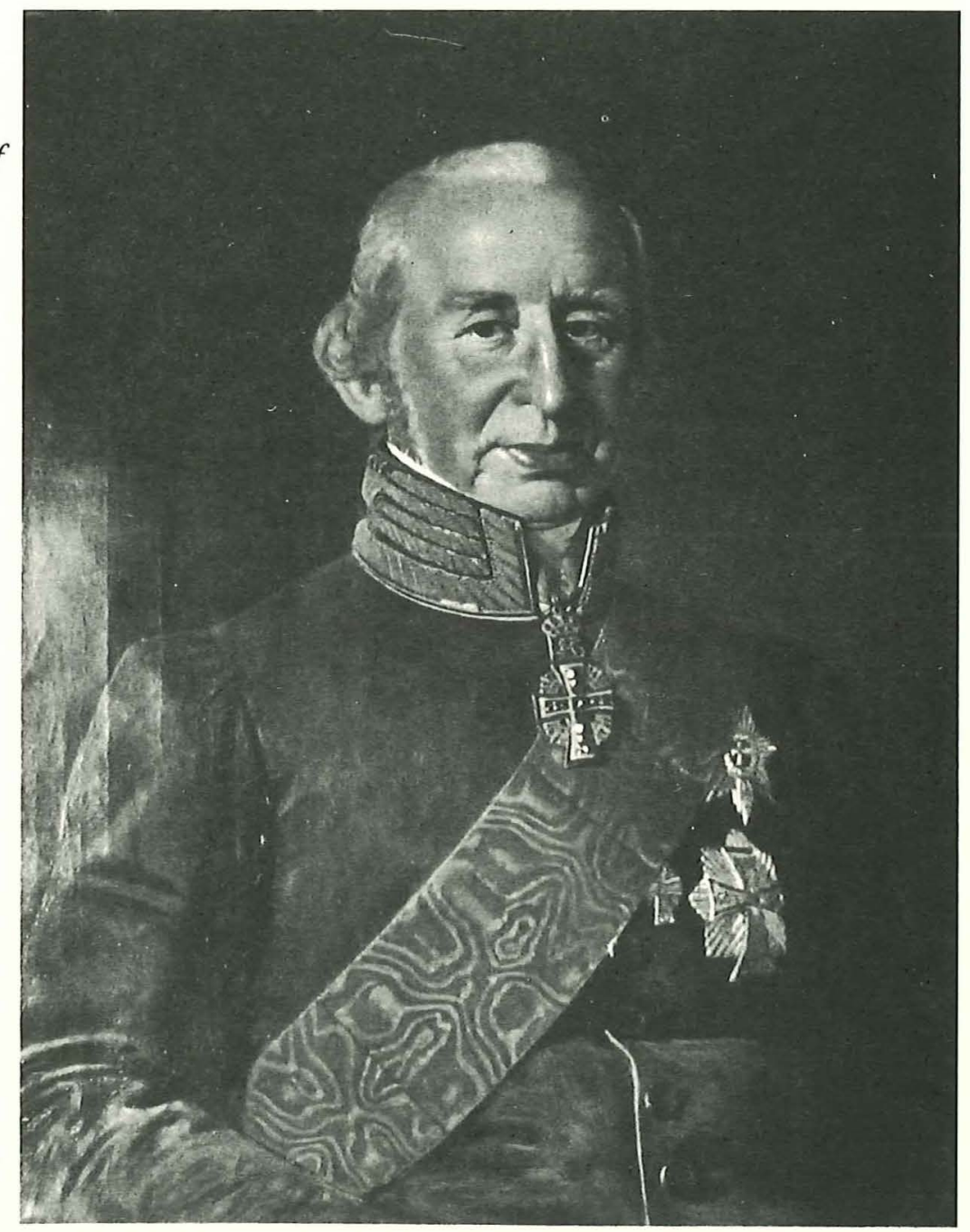

beskrev i en anden afhandling til det danske Videnskabernes Selskab. ${ }^{5}$ Instrumentet omtaltes i udenlandske skrifter, ${ }^{6}$ og dets ide ligner meget senere tiders relæer. Men det var mere kompliceret i brug end samtidige elektrometre af engelsk konstruktion, og fandt derfor ikke udbredt anvendelse.

Den agtelse Hauch nød i naturvidenska- belige kredse i Europa illustreres af en bemærkning i det ansete tidsskrift Gilbert's Annalen der Physik. I omtalen af Ørsteds opdagelse af elektromagnetismen i 1820 , erkender udgiveren at han først ikke troede på Ørsteds bekrivelser af sine forsøg. Men da han erfarede om blandt andre Hauchs tilstedeværelse ved forsøgene, 
34 ændredes hans holdning.?

I Holland findes det smukkeste af de bevarede, fysiske kabinetter fra den tid, nemlig det, der skabtes af Martinus van Marum. Hans samlinger kan ses i det såkaldte Teylers Museum i byen Haarlem, hvor de stadig findes i de oprindelige lokaler, hvorfra Van Marum var i kontakt med hele det europæiske naturvidenskabelige fællesskab og beskæftigede sig med alt, hvad der angik de nyeste naturvidenskabelige landvindinger. Også Hauch og Thomas Bugge, der var professor i astronomi ved Københavns Universitet, besøgte Haarlem; og Niels Hofman-Bang, der var stamherre på Hofmansgave, korresponderede med Van Marum om botaniske spørgsmål.

Men udover fysiske kabinetter med seriøse videnskabelige gøremål var der, som nævnt, også medlemmer af overklassen, som fandt et statussymbol $i$ at eje smukke instrumenter. Den extravagante greve Jørgen Scheel, der ejede flere godser på Djursland, anskaffede ved samme tid, altså omkring år 1800 , en samling instrumenter. Han var kendt som «den vilde greve», der strøede om sig med penge til rejser, selskabelighed og anskaffelse af kostbarheder, og derved stiftede en ufattelig stor gæld, så han til sidst blev umyndiggjort. Hans besiddelser kom på tvangsauktion, også hans instrumentsamling, for hvilken auktionskataloget med titlen Physikalske, astronomiske og mathematiske Instrumenter indeholdt 83 numre, der dog ikke alle kan regnes som egentlige instrumenter. ${ }^{8}$ Allerede en af hans forfædre havde haft fine instrumenter af messing. På Skokloster slot i Sverige findes et tegneapparat, signeret med navnet Jørgen Scheel, som er krigsbytte fra svenskekrigene i
Jylland. I England er der et eksempel på en vidtløftig greve, the Earl of Egremont, som ejede Petworth House i Sussex. Han installerede en elskerinde på sit gods. Det var der måske ikke noget usædvanligt i, men han anskaffede et kemilaboratorium til hende, så hun kunne have lidt adspredelse i sin fritid. Og det var ikke bare et lejetøjssæt, hvilket kan ses af ca 120 stykker videnskabeligt apparatur, som stadig findes.

Ud over Europa fandtes formentlig hundreder af naturvidenskabelige kabinetter af forskellig art og størrelse, og til forskellige formål. Et af de virkelig fornemme var Bonnier de la Mossons fysiske kabinet i Paris. ${ }^{10} \mathrm{I}$ de seneste 10-20 år er flere blevet beskrevet. De står som monumenter for en tid, hvor kravet om oplysning for folket vokser. Trykketeknikken gjorde anskaffelsen af bøger økonomisk overkommelig, undervisning sattes i system, hvorved menigmands nysgerrighed fandt næring, og kommunikationen mellem Europas videnskabsdyrkere blev livligere. Det marked, der derved opstod, blev grebet af en mængde håndværkere, som med stor dygtighed søgte at imødekomme efterspørgslen efter instrumenter. Det blev til en omfattende industri, der navnlig florerede i Holland og England.

Ved at begynde med at omtale Hauchs Samling og sætte den i relation til andre samlinger af samme art og fra samme tid, har jeg tilladt mig så et sige at starte i midten. Tiden var jo ca 200 år efter Galilæi, 100 år efter Newton; 100 år før Einstein og 200 år før vor tid. 
Astrolabiet er et af de tidligste, kendte instrumenter. Kunne bruges til måling af himmellegemers hojde over horisonten og dermed til tidseller stedsbestemmelse. $P a$ billedet astrolab fra 1556, på Museo di Storia della Scienza $i$ Firenze, gjengitt etter museets katalog.

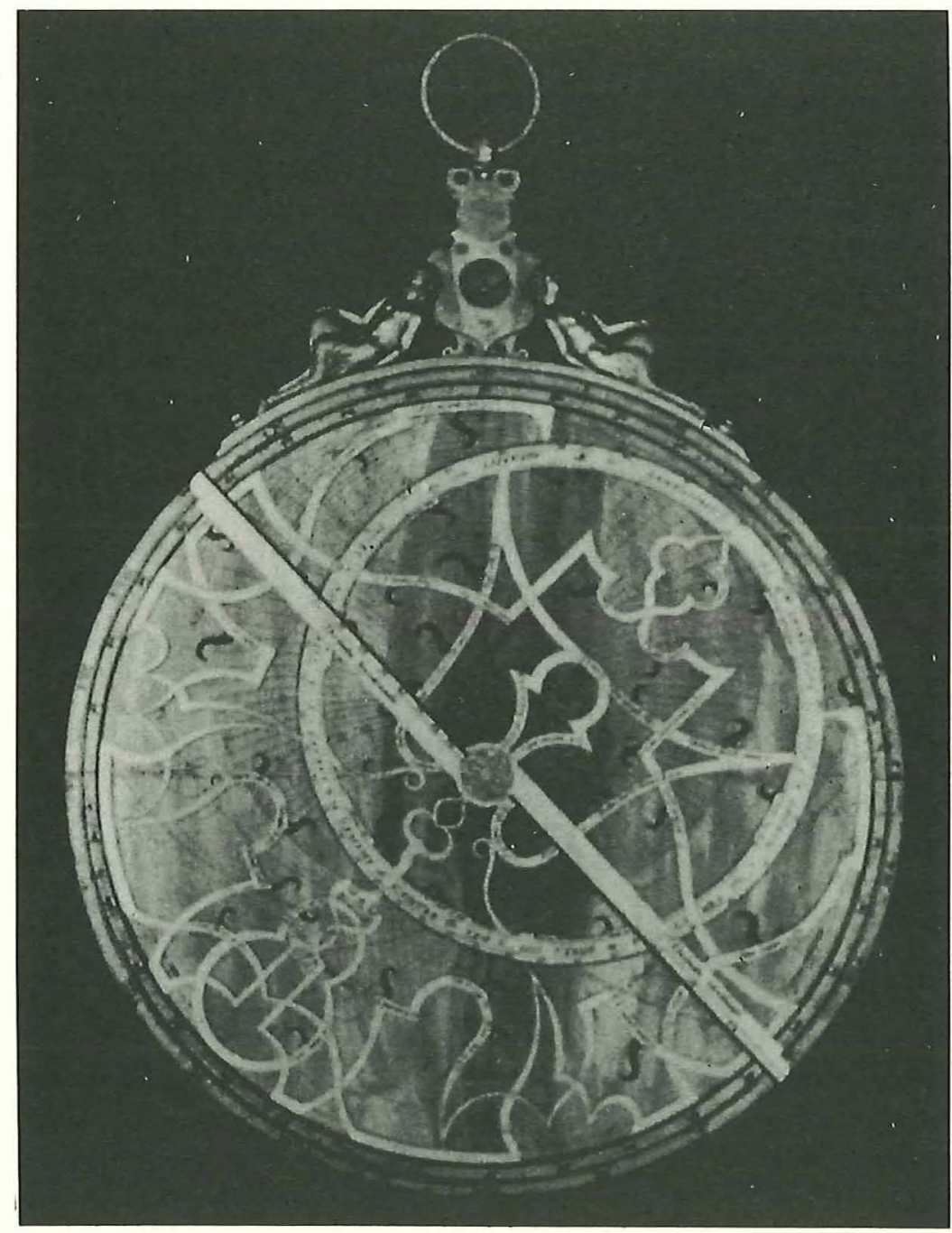

\section{HISTORISK PERSPEKTIV.}

Instrumenter fandtes naturligvis længe før de fysiske kabinetters tid. Det er svært at forestille sig, at det skulle være muligt at bygge de ægyptiske pyramider uden en eller anden form for nivellerinstrument. Stonehenge i England anses af mange for i sig selv at være et flere tusind år gammelt astronomisk instrument. Og mon ikke græske billedhuggere har haft krumpassere eller lignende til at måle på deres modeller og figurer? I dette afsnit vil jeg prøve at trække en livslinie, der kortfattet antyder udviklingen af en type instrument som har haft direkte indflydelse på udviklingen 
36 af selve vor kultur.

I Ptolemæus' værk Almagest beskrives instrumenter, der illustrerer det stade, som hellenistisk astronomi stod på, og disse instrumenter blev udgangpunktet for vesteuropæiske astronomers arbejde efter at oversættelsen af Almagest var blevet tilgængelig i 1100-årene. For eksempel beskriver Ptolemæus en armillarsfære, ${ }^{11}$ som var et instrument i næsten moderne forstand. Ved hjælp af sigter har det kunnet anvendes til måling af celeste vinkler, de målinger som til alle tider har været astronomernes vigtigste opgave. Men det havde også didaktiske og pædagogiske formål. Derimod er det usikkert om det også har haft mere almindelig praktisk anvendelse, for eksempel i forbindelse med tidsmåling.

Den ældste type instrument, hvoraf der findes et antal bevarede eksemplarer, er astrolabiet. Man mener at det har været kendt før Ptolemæus' tid, ${ }^{12}$ og omkring år 1000 kom det til Europa med Islams udbredelse fra Afrika gennem Spanien. Det har formentlig fundet praktisk anvendelse ved navigation i det Indiske Ocean, og har vel også hjulpet karavaner til at orientere sig efter stjernerne $\mathrm{i} ø$ rkenen, når man vandrede om natten.

Ved at hænge astrolabiet på tommelfingeren kan man med en drejelig alhidade sigte efter solen eller en kendt stjerne og måle dens højde, det vil sige vinkel over horisonten. På astrolabiets anden side findes en skive med en række stjerner markeret i deres rette stilling på himlen i forhold til hinanden. Stjerneskiven, kaldet Rete, kan drejes over en slags koordinatsystem for himlen, og man har derved en analog computer, som fandt anvendelse til tidsbestemmelse, retningsbestemmelse, og som astronomisk undervisningsapparat. ${ }^{13}$ Det er ikke uvæsentligt, at det også brugtes af astrologer. Man kan stadig købe en version af astrolabiet, lavet af pap og plast, til brug for orientering på stjernehimlen. Det hedder Stjernehimlen året rundt.

Astrolabiet kom til at danne grundlag for de instrumenter til vinkelmåling, der blev de nødvendige redskaber op gennem tiden for kortlægningen af vor verden. Men i sig selv var det ret lille, transportabelt, og ikke særlig nøjagtigt. Det har hovedsageligt tjent praktiske formål; og havde man først forstået at bruge det, var det vældig handy. Men forudsætningen for at kunne fremstille et astrolabium var, at man kendte stjernernes positioner på firmamentet. Derfor måtte man have tabeller over stjernerne, og sådanne havde allerede Ptolemæus lavet; disse tabeller skulle gerne være nøjagtige og revisioner af dem kunne kun udarbejdes ved hjælp af bedre instrumenter, der til gengæld ikke behøvede at være transportable. De opstilledes i faste observatorier. Et eksempel på en sådan instrumenttype er kvadranten, hvormed man med god nøjagtighed kunne måle himmellegemers kulminationshøjde, det vil sige vinklen over horisonten, ved passage af stedets meridian i syd.

Tartarfyrsten Ulug Beg byggede i 1400årene et astronomisk observatorium i Samarkand. Her fandtes en bygning som rummede en kvadrant med en radius på ca 40 meter opbygget i stedets meridianplan. Tilbage er nu kun ruinen af kvadrantens nederste del. For at aflæse kvadranten måtte man spadsere ad trappetrin langs med den cirkulære skala, mens man sigtede ud gennem en åbning foroven i kvartcirklens centrum. 100 år senere byggede Tycho Brahe sin berømte murkvadrant på Hven. Den havde en radius på ca 2 meter; 
men med den af Tycho opfundne særlige sigteanordning var den alligevel mere nøjagtig.

Kvadranten fandtes også som bærbart instrument. En kvartcirkel med sigter langs en radius og en lodsnor benyttedes både $\mathrm{i}$ astronomien og til landmåling. Senere forsynedes kvadranten med en alhidade, hvis stilling kunne aflæses på 90 grader skalaen.

I anden halvdel af 1400-årene trængte en særlig robust udgave af kvadranten frem som navigationsinstrument, nemlig $s ø$-astrolabiet (eng. mariner's astrolabe). Et instrument, der bestod af en messingplade og lodsnor var ikke hensigtsmæssig på et skib i bølgegang og blæst. Derfor udførtes søastrolabiet åbent, så det bestod af en gradueret halv- eller helcirkel med egre ind til centrum, og med en kraftig alhidade drejelig om centrum, og støbt i messing så det blev tungt.

Hvis det er solhøjden, man skal måle, er det meget ubehageligt at skulle sigte direkte imod solen. Davis kvadranten, der blev opfundet i 1595, havde den fordel, at man observerede med ryggen til solen, idet man betragtede den skygge, som solen kaster på en lille plade. Instrumentet hedder på engelsk en backstaff.

Det betød et vældigt fremskridt, da man i Holland i begyndelsen af 1600-årene fandt på at sammenbygge linser til linsesystemer, kikkerter. Gennem teleskopet åbnedes vejen til det store univers, og gav ikke blot mulighed for at undersøge for eksempel månens overflade, men kunne også benyttes som et sigteinstrument, der kunne erstatte de hidtidige alhidader med trådsigter.

Mikroskopet lod os se ind i en verden, der hidtil havde været usynlig på grund af sin lidenhed. Og da englænderne Bird, opfandt og forfinede en delemaskine for cirkulære skalaer, kunne inddelingerne gøres så små, at de ikke kunne aflæses med det blotte øje. Mikroskopet kom da til at finde anvendelse ved aflæsning af måleinstrumenters skalaer. På denne måde kunne man måle astronomiske vinkler med en nøjagtighed på mindre end et buesekund.

Den helt store udbredelse for vinkelmåling nåede oktanten, der blev opfundet samtidig af englænderen John Hadley og amerikaneren Thomas Godfrey i 1730 . Ved refleksion i et spejl kunde den vinkel, man skulle måle, halveres, således at kvadrantens 90 grader kunne reduceres til en skala på 45 grader, hvorved instrumentet kunne gøres mindre. Samtidig fik oktanterne en mere robust konstruktion, så de blev særdeles velegnede i søfarten. Endvidere kunne aflæsningen af instrumentet gøres mere præcis ved hjælp af transversaler og senere nonius. Ved transversaler havde man for eksempel 5 koncentriske skalaer med inddelinger på den yderste og den inderste. Med skrå streger forbandt man en inddeling på den inderste skala med den næste inddeling på den yderste. Skråstregens skæring af de mellemliggende cirkler angav femtedele, og man regnede på denne måde med at kunne måle tiendedele af en grad. Nonien blev opfundet af franskmanden Pierre Vernier omkring 1630 og beror på, at man ved forskydning af en lille skala aflæser en position, hvor to skalastreger står lige over for hinanden. Med oktanter af almindelig kvalitet kunne man aflæse med en nøjagtighed på omkring 3 bueminutter.

Med den florissante handel over havene i 1700-årene var markedet vidt åbent, og 
38 oktanter blev massefremstillet. Med de tidligste oktanter sigtede man gennem et lille hul, men senere forsynedes de med sigtekikkert. Der blev behov for at måle større vinkler, da man fandt på at benytte stjerners afstand fra månen til at kontrollere tiden til søs. Oktanten afløstes da af sekstanten, der kunne måle 120 grader og bordacirklen, der klarede en hel cirkel. Ved den første ruteflyvning over Nordpolen i 1950erne navigerede man stadig med sekstant.

Også landmåling er baseret på nøjagtige målinger af vinkler. Primitive sigte-alidader, som var til at lægge på måleborde, fik anbragt kikkertsigte. Kvadranten tilpassedes som topografisk måleinstrument, hvor vinkler kunne aflæses og afsættes på tegningen. Den udvikledes gennem mange år til teodolit, et instrument som findes $\mathrm{i}$ mange varianter. I dag bruges en slags teodolitter med reflekteret laserlys.

Denne korte oversigt over instrumenter til optisk måling af vinkler antyder den betydning disse har haft for udviklingen af vor civilisation: de blev en væsentlig forudsætning for søfart, kortlægning, tidsmåling og industrielt håndværk, - søjler der bærer vor kultur.

\section{EKSPERIMENTEL FILOSOFI}

Man anvendte indtil 1600-årene ofte betegnelsen matematiske om den slags instrumenter, som vi her har omtalt. Astronomi regnedes jo for en matematisk videnskab, og hensigten var at måle.

Men efter Galilæi og Newton opstod en helt ny type fysikapparater. Det var dem, der skulle bruges til at anskueliggøre, hvordan naturen fungerede. Det var for eksempel skråplanet med en rullende cylinder, faldmaskinen, hvormed det frie fald kunne undersøges, centrifugalmaskinen, hvormed man undersøgte roterende legemers opførsel, vægtstænger, trisser, kasteapparater, og ikke mindst luftpumpen, hvormed man undersøgte virkninger i vakuum, og meget mere. Disse apparater var ikke i sig selv måleredskaber, men man kunne foretage målinger på de bevægelser, som apparaterne kunne udføre (faldmaskinen), og man kunne selv skabe ekstreme forhold, hvorunder fænomener kunne studeres (luftpumpen). Disse apparaturer har man betegnet filosofiske instrumenter. Så i løbet af 1700-årene fremstod værksteder, der kunne reklamere med at være Mathematical, optical and philosophical Instrument Maker. Betegnelsen filosofisk instrument kommer fra, at man begyndte at behandle de fænomener eksperimentelt, som man tidligere kun havde betragtet som filosofiske problemer. Man talte om eksperimentel filosofi og så er der jo ikke langt til det filosofiske instrument.

I løbet af 1700-årene trængte en ny naturkraft sig påtrængende frem: statisk elektricitet. Den kreativitet, der udvistes i konstruktionen af apparater, hvormed man fremstillede og demonstrerede denne elektriske kraft, er kolossal. Og nu er vi kommet til den periode, hvor de tidligere nævnte fysiske kabinetter blev en del af den kulturelle verden. Elektricitet blev tillagt hemmelighedfuld kraft, helbredende virkning og var en kilde til morskab og underholdning. Bortset fra nogle såkaldte elektrometre hen imod slutningen af perioden, undersøgte man blot fænomenet kvalitativt. Og selv elektrometrene var ikke måleinstrumenter i moderne forstand, men de kunne bruges til relative målinger. Man vandt erkendelse ved hjælp 
af lynildhuse, volta pistoler (antændelse af brint), elektrisk regn og mange andre fantasifulde eksperimenter, som uden tvivl har tryllebundet tilskueren.

Men der var mange andre fænomener, som interesserede indenfor fysikområderne varme, lys, lyd, kemi m.m., og vi støder her på det problem, at der ikke på dansk findes nogen fælles betegnelse for instrumenter, der har til formål at måle og at illustrere naturen.

\section{«SCIENTISKE INSTRUMENTER»?}

Betegnelsen fysikinstrument er for snæver. De instrumenter, som vi her taler om, rækker ud over fysikkens område og vi savner for dem en dækkende fælles betegnelse.

Jeg følte det meget direkte, da jeg fornylig opsøgte en række museer, institutioner og private for at registrere gamle instrumenter. Mit ærinde krævede oftest en længere forklaring, og jeg erfarede, at ordet instrument som regel er synonym med musikinstrument. Men hvad skal vi kalde disse fysikinstrumenter?

Verdensudstillingen i London i 1851 var på mange måder skelsættende. Englænderne opdagede, at verden udenfor Storbritannien var ved at hale ind på dem, og der blev derfor oprettet et Department of Science and Art. ${ }^{14}$ Det var formodentlig første gang betegnelsen science anvendtes officielt. Ordet Scientist skabtes af filosofiprofessor i Cambridge, William Whewell, i 1834, og har formentlig givet ideen til departementets navn. Den tidligste brug af betegnelsen Scientific Instrument synes at være i Amerika, og det blev der brugt som betegnelse for undervisnings- instrumenter. Scientific instruments er nu den anerkendte betegnelse på engelsk. Den nærmeste danske oversættelse må vel være Naturvidenskabelige instrumenter, som vil være i tråd med det tyske Naturwissenschaftliche Instrumente. Jeg synes det lyder lidt tungt og klodset. På fransk har man Instruments scientifique og italienerne bruger Strumenti scientifici. Den opmærksomhed disse instrumenter har opnået i løbet af de seneste årtier, og den erkendelse, man er kommet til af deres selvstændige betydning for videnskabshistorien og kulturhistorien, berettiger til en selvstændig og entydig betegnelse. Hvad med: Scientiske instrumenter? Det vil være i overensstemmelse med den meget omfattende engelsksprogede litteratur, det placerer disse artifakter klart. Betegnelsen er hermed foreslået.

Lad os se lidt nærmere på, hvilke områder, der i dag regnes med til scientiske instrumenter. Det bliver et spørgsmål om at definere. En engelsk registrant, der udkom i 1992, bruger det meste af en side på at redegøre for, hvad der er medtaget $\mathrm{i}$ registranten, og navnlig hvad der ikke er medtaget, og kommer med denne definition:

The term 'scientific instrument' is used to cover both the artefacts normally constructed by a scientific instrument maker and the relatively few surviving instruments actually designed by, used by, or constructed for distinguished scientists in their research. $^{15}$

En irsk registrant ${ }^{16}$, der udkom i 1990 anfører at historic betyder instrumenter fremstillet op til første halvdel af vort århundrede, idet man er mere og mere restriktiv med at medtage instrumenter jo 
40 senere de er fremstillede. Og definitionen på et scientific instrument er (1) instrumenter brugt af professionelle, for eksempel landmålere (teodoliter) og navigatører (sekstanter); (2) instrumenter brugt til undervisning og demonstrationer af 'scientific principles' ('fysikinstrumenter'?); (3) instrumenter brugt i 'scientific research'; og endelig (4) udvalgte instrumenter fra mere privat brug som barometre, ure og legetøj. Urene skal dog være enten skibskronometre, astronomiske ure eller ure, der indgår i større samlinger, som registreres i deres helhed.

Professor i scientific instruments ved Imperial College i London, Gerard Turner, der er den største kapacitet på området har afgrænset scientific instruments således: (1) physical and analytical instruments; (2) professional instruments (hermed menes instrumenter for landmåling, navigation, arkitektur, meteorologi, toldvæsen og lignende); (3) teaching instruments; og (4) recreational instruments (det er for eksempel kalejdoskoper, stereoskoper, optiske bedrag "trylleting» og lignende). ${ }^{17}$

Problemet er diskuteret af Deborah Jean Warner, som kommer til følgende deprimerende konklusion:

... nothing in science is more difficult than definitions. This is certainly true of 'scientific instruments', a term which means different things to different people, and whose meaning has changed substantially over time. ${ }^{18}$

I registrering af danske instrumenter, som jeg har været engageret med for nylig, har jeg medtaget: instrumenter fra (1) uddannelse og forskning; (2) industri og handel; (3) privat brug (barometre, legetøj etc); og
(4) diverse (herunder ting der ikke passer ind $\mathrm{i}$ de foregående kategorier, men som skønnes at kunne fă historisk værdi). ${ }^{19} \mathrm{Jeg}$ indrømmer svagheden ved den sidste kategori. Men jeg stødte gentagne gange på ting, som gav mig problemer. For eksempel en Malling skrivemaskine og et par meget tidlige glødelamper, der indgår i en større instrumentsamling. Jeg følte ikke, at de skulle trækkes ud af den samlede registrering, men kunne ikke placere disse ting i en sædvanlig instrument-kategori. Min holdning blev generelt den, at hvis der er tvivl om, hvorvidt en ting skal med i registranten eller ej, så kommer den med; hellere en ting for meget end en ting for lidt.

Der er skabt tradition for at lægevidenskabelige instrumenter holdes adskildt fra andre scientiske instrumenter. Årsagen hertil er uklar, for der er mange instrumenter, der hører til begge steder, for eksempel mikroskoper. Men det skyldes måske, at lægevidenskabelige instrumenter tidligt samledes på museal basis, og tidligt har haft en stor offentlig bevågenhed; det er måske forståeligt, da ting som trepanationssæt og klystersprøjter bogstaveligt har været tæt inde på livet af folk i mange år; og kirurgiske instrumenter har nok altid haft samme pirrende interesse, som har gjort moderne lægeromaner populære. $\mathrm{Og}$ så er det jo også ofte sådan, at genkendelsens glæde er større end glæden ved at erfare nyt; og mange har set og følt en læges apparater.

\section{FYSIKMUSEER}

Hvad er et Fysikmuseum, og hvordan bør det indrettes? De fleste fysikmuseer er enten: (1) opstået af samlinger, der har tilhørt personer eller institutioner, og som så 


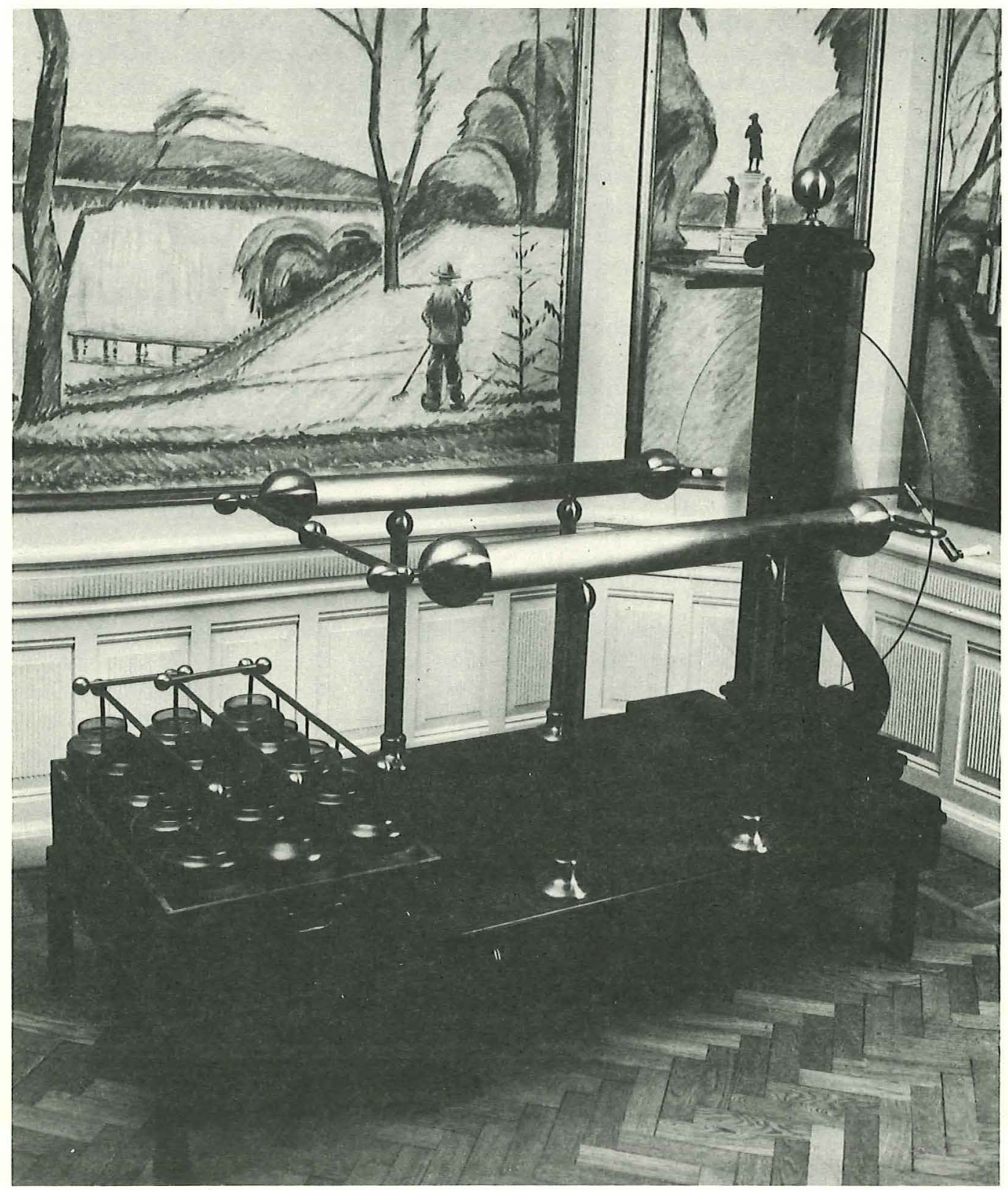

Fra "Hauchs Physiske Cabinet» på Soro Akademi opstillet $i$ "Vanget». En af de store elekticermaskiner, sign.: "Dumotiez Freres a Paris 1796». Foto: Hemming Andersen. 
42 er formeret $\mathrm{i}$ en organisation, der har til formål at drive museum, eller (2) er vokset ud af en undervisningssituation.

Ethvert museum bør bygge på et fundament af folkeoplysning. J.A. Bennett, som er kurator for The Whipple Museum for the History of Science i Cambridge, deler fysikmuseer ('Science Museums') i 3 slags ${ }^{20}:$ (1) det traditionelle museum, med samlinger fra teknologi og/eller naturvidenskab; det er samlinger, der kan formeres i faglig eller historisk sammenhæng; Teknisk Museum i Helsingør hører til denne kategori. (2) det renoverede historiske industriforetagende; her får den besøgende indblik i forrige generationers liv og arbejdsvilkår; disse vil være teknologisk prægede og ofte også have et socialpolitisk islæt; det nærmeste vi kommer her i Danmark er nok Elmuseet i Bjerringbro. (3) experimentariet, eller science centret, som ikke har historiske instrumenter at vise frem, men har genskabt de gamle apparater $\mathrm{i}$ moderne materialer og indrettet dem, så publikum selv kan manipulere dem; disse er udpræget pædagogiske. Et sådant er nylig indrettet på Tuborg i København.

Disse 3 grupper kan naturligvis overlappe, men i praksis må der på een eller anden måde sættes skarpe grænser imellem dem. Sættes disse grænser ikke mellem museerne, så må der indenfor det enkelte museum være en opdeling, hvorved der sondres mellem den pædagogiske afdeling og afdelingen med nationale, historiske, og ofte skrøbelige, artifakter. Grænsedragningen er ikke altid let. Ønske om at vække den almene interesse medfører fristelse til at gamle instrumenter gøres tilgængelige. Men det bør ikke ske. Foruden den umiddelbare skrøbelighed skal der også tages hensyn til en original overfladebehandling af for eksempel messinginstrumenter; sådanne bør ikke berøres uden stofhandsker.

Endelig er der hensynet til dem, der søger mere i dybden, og det er en kategori af museumsgæster, der ofte lades i stikken. Ikke mindst efter at en del af museernes indtægt skal komme fra opkrævning af entre, er det forståeligt, at man har måttet satse på popularitet, og det har museerne tilsyneladende været dygtige til, eftersom besøgstallet jo ikke synes at være faldet. Men jeg tror, at det er et tilbageskridt, at museumsgæster ikke kan komme igen for at undersøge en sag nærmere, uden at skulle betale entre gentagne gange. $\mathrm{Nu}$ gælder det nok ofte om at se så meget som muligt 'når man alligevel har betalt entre'.

For et par år siden besøgte jeg National Museum of American History i Washington, og jeg havde hørt, at der fandtes nogle måleinstrumenter fra 1700 -årene $\mathrm{i}$ en bestemt udstilling. Udstillingen viste sig at være et kæmpe panorama, der illustrerede livet i nybyggertiden. Der var prærievogn, arbejdsredskaber osv, et flot kalejdoskop over livet dengang, med giner klædt på som landmand og husmoder. $\mathrm{Og}$ nede $\mathrm{i}$ et fjernt hjørne lå et lille beskedent instrument, så vidt jeg husker en jævn oktant, som man ikke ville få øje på med mindre man søgte. Detaljen drukner i detaljemængden. Men den, der kommer uden forudsætninger, kan naturligvis her få inspiration til at søge mere udførlig viden.

På det samme museum var der også en udstilling, kaldet det elektriske kys, som elegant og meget pædagogisk oplyste om naturvidenskab. En gine klædt på som en fin dame fra 1700-årene står på en isole- 
rende skammel og oplades elektrisk af en stor elektricermaskine og skal til at kysse en ungersvend, der står uisoleret. Hvem vil ikke af en sådan udstilling kunne fristes til at eksperimentere med elektricitet? En lignende pædagogisk virkning opnår Elmuseet i Bjerringbro ved et tableau, der viser en fornem dame få elektroterapi under kongelig bevågenhed. Elektricitet kan skam også helbrede mod fordærv.

Fysikmuseer er på vej til en renaissance, - eller er måske i realiteten ved at blive født. Science Museum i London har i 1992 nyopstillet George IIIs fysiske kabinet; og Leids physisch Kabinet fra universitetet i Leyden blev i 1991 nyåbnet i et komplet fornyet Museum Boerhave. Begge steder er der tale om millioninvesteringer.

Peter de Clercq, der har stået for projektet i Leyden gør rede for de principper, der har ligget til grund for planlægningen, og de er nok værd at hefte sig ved, da Museum Boerhave er et af de mest betydende History of Science Museums i Europa. Han understreger, at udstillingen er helt objekt-orienteret. Fysikmuseer bruger ofte megen plads på forklarende tavler, videoer etc, men den slags har man der været sparsom med. "Vi giver ikke undervisning illustreret med udstillingsgenstande», siger le Clercq, "vi har en samling, og det er den, vi vil vise». Alle genstande er autentiske historiske artifakter, som så vidt muligt er arrangeret i kronologisk orden, og ikke ubetinget ordnet efter fag. Man har således $\mathrm{i}$ det samme rum landmåler instrumenter, model af en vindmølle, teleskoper og udstilling om Carl Linneaeus. På denne måde understreges museets historiske koncept. Genstandene er kun sparsomt forsynede med beskrivelser på hollandsk og engelsk, men er så vidt muligt anbragt så de kan ses fra alle sider. Der er altså god mulighed for at studere uden at berøre. Et righoldigt sortiment af katalogmateriale kan købes af dem. der vil vide mere. En særlig afdeling af museet indeholder hands on moderne modeller, altså et eksperimentarium, hvor man regner med udskiftning til nye emner hvert $5^{\prime}$ år. ${ }^{21}$

Der ligger heri en tendens bort fra overdreven popularisering og hen imod at vise den $æ$ gte vare på dens egne præmisser. Der ligger en afstandtagen fra den pædagogiske revolution, der fandt sted for 20-30 år siden og som satte dybe spor, idet balancen mellem belæring og underholdning blev forskudt til fordel for underholdningen. Resultat ses i dag i massemedierne, hvor Ekstrabladet og radioens program 3 kan score høje læser- og lyttertal på grund af de minimale intellektuelle krav der stilles, og som skyldes de principper for undervisning og opdragelse, der blev dominerende. Også i museumsverdenen har man måttet følge med strømmen.

Dr Robert Anderson, direktør for British Museum, beklager at «in many museums the earlier paternalistic attitudes have been overtaken by popularism ${ }^{22}$ En sådan udtalelse, og de næunte præmisser for det nye Museum Boerhave kan måske tyde på, at der er et holdningsskift på vej. Jeg mener ikke, at museer af den grund behøver at blive kedelige; måske kunne man stræbe efter at det interessante blev vægtet tungere på bekostning af det underholdende? Derfor må også scientiske instrumenter naturligvis udstilles i kontekst med andre grene af vor kultur. Med Robert Andersons ord: "scientific instruments are by no means confined to science museums. And neither should they be». 


\section{KONKLUSION}

Jeg begyndte med en omtale af Hauchs Samling og vil slutte samme sted. Efter 3/4 århundrede på pulterkammer har den siden 1976 været under opstilling i bygningen Venget på Sorø Akademi. Under opstillingen har det været tilstræbt, at apparaterne så vidt muligt blev beskyttet bag glas, og udenfor besøgendes rækkevidde. Jeg har desværre ikke haft fantasi og plads til at opstille samlingen på en sådan måde, at dens oprindelige brug kunne illustreres godt nok. Det er blevet en udstilling af instrumenterne næsten uden egentlige beskrivelser, og uden at deres eksperimentelle sammenhæng illustreres.

Der har ikke været økonomi til at holde almindelige åbningstider, og de cirka 300 besøgende, der alligevel har været på årsbasis, har henvendt sig med ønsker om at se samlingen. Ved rundvisning eller foredrag har det da i stor udstrækning været muligt at imødekomme gæsternes specielle interesser. Det har på sin vis fungeret udmærket, og det er blevet klart for mig, at en sådan instrumentsamling ikke er noget folkeligt tilløbsstykke, og næppe heller kan blive det, med mindre det sættes i en større sammenhæng. Det er et museum man opsøger, ikke et tidsfordriv. Det kan ikke sammenlignes med et kunstmuseum, hvor man efter et besøg godt kan udtrykke sine personlige meninger om udstillede kunstværker; efter et besøg på et fysikmuseum skulle man gerne føle at man har lært noget.

Desværre er fremtiden for Hauchs samling usikker. Opstillingen har været bekostet af fremmede fonde, som har haft vision til at se samlingens betydning, mens ejeren og lokalsamfundet ikke har ydet reelle bidrag. Der er ingen penge til løbende restaurering og pasning, og rygter vil vide at samlingen nu skal flyttes, fordi lokalerne skal bruges af ejeren til andre formål. Det synes derfor uforståeligt, at man ikke har villet acceptere et tilbud om deponering af samlingen på det nye videnskabshistoriske museum, Steno Museet, i Aarhus. Her ville den have faet en central placering $\mathrm{i}$ en større sammenhæng, den ville blive passet professionelt, og den ville blive offentligt tilgængelig. Alternativet er naturligvis, at ejeren, Sorø Akademis Stiftelse, erkender sit kulturelle ansvar og skaffer samlingen lignende forhold, som den ville opnå på Steno Museet. Dette ville muligvis kunne opnås i Sorø, men vil kræve store investeringer og løbende omkostninger.

Da Hauch som 72-årig så, at han ikke mere magtede sin store samling, anbefalede han kongen, at den blev skænket til det nyopbyggede Sorø Akademi, hvor den kunne komme til sin ret og gøre gavn. En overflytning til det nybyggede Steno Museum vil således ikke være uden historisk parallelitet. Men dette er for så vidt ikke væsentligt. Af betydning er alene samlingens tarv. Hauchs samling er et nationalt klenodie, som skal bevares og holdes samlet. Den gamle Overhofmarskal, Elefantridder, Præses for Videnskabernes Selskab og meget, meget mere fortjener, at hans samling kommer til at indgå $\mathrm{i}$ en værdig naturvidenskabelig og historisk sammenhæng.

\section{SUMMARY}

Physics and Museum: Hauch's physical Cabinet

Adam Wilhelm Hauch (1755-1838) was Lord Chamberlain to the Danish King Frederik VI. He 
acquired a large collection of physical and chemical instruments, a physical cabinet. Here he carried out experiments, subsequently taking part in discussions of the latest scientific discoveries.

Many such physical cabinets emerged during the Age of Enlightenment in Europe. Some, such as Hauch's, were used for serious research, others were for entertainment, others again were primarily status symbols.

Francis Bacon had been the leading proponent for making observations and measurement the basis for theorizing about the world. Societies or academies had been formed by scientists, for example the Royal Society in London, and these became hotbeds of new discoveries, and publishers of scientific papers. Knowledge was occasionally dispersed to the public by itinerant lecturers, who travelled with a load of demonstration apparatus, often made by themselves.

Physical cabinets may be said to cover the field between these two poles, and varied widely in size and scientific status. There were hundreds of them in Europe, and they became an important market for craftsmen making instrument. The trade became extensive, particularly in England, Holland and France.

Although these physical cabinets flourished during 17 th and 18 th centuries, instruments were of course, known both before and after this time; for example the important task of measuring celestial angles was the basis for astronomy and surveying. This paper attempts to present an historic perspective of the development of angle measuring instruments, including astrolabe, quadrant, octant, sextant, theodolites etc etc.

These instruments were all intended to measure, and were therefore called 'mathematical instruments'. Following Galileo and Newton, a new type of apparatus emerged: 'philosophical instruments'. These were intended to illustrate the behaviour of nature, often by exaggeration, e.g. the gravitational fall was examined by a slope, and the vacuum pump produced extreme low pressures.

The Danish language does not have a word covering the English 'scientific instrument'. A suggestion is made, and the definition of the word is discussed with reference to articles in English.

The collection of instruments in museums is discussed with reference to the three types suggested by J.A. Bennett. References are made to the newly opened George III collection at Science Museum, London and Boerhave Museum, Leiden. It is felt that the recent decades' predominant popularization is being taken over by attempts to show artifacts in their own right, putting weight on presentation rather than explanation.

The paper concludes with the regret that the future of the important Danish 'Hauch's Collection' is uncertain. It will probably be removed from its present location, as the owner wishes to use the premises for other purposes. No economic support has been allocated for restoration and maintenance. A suggestion two years ago to deposit the collection in the new History of Science Museum, Steno Museet, in Aarhus, has not been accepted. As part of our national heritage the Hauch Collection must be preserved as a unit.

\section{NOTER}

0. Denne artikkel er en trykt verson af forelæsning holdt af forfatteren i Museumshøjskolens museologiske forelæsninger på Nationalmuseet 3. marts 1994.

1. Se: Mogens Bencard «Museerne og Verdensordenen. Kunstkammerets Opståen og Grundide» i Nordisk Museologi 1993.1

Endvidere: Otto Andrup Den kongelige Samling på Rosenborg gennem hundrede Aar I: Den chronologiske Samling, 1933; og: Bente Gundestrup Det kongelige danske Kunstkammer 1737 Nationalmuseet 1991, pXXV ff.

2. Se for eksempel: Olaf Pedersen og Mogens Pihl 
Historisk Indledning til den klassiske Fysik, København 1963, p 199.

3. En af de kendteste var James Ferguson (171076); se John R. Millburn Wheelwright of the Heavens, Vade-Mecum Press, 1988.

4. Resultater af en Deel anstillede Forsog med Hensyn til den af Hr Professor Wiirtzer $i$ Bonn angivne Forvandling af Vandet til Salpeterstof- eller Qvalstofgas. Vid. Selsk. Skr. I Deel, II Hæfte, 1795. p201ff.

5. Forsog til et forbedret Udlade-Electrometer Vid. Selsk. Skr. Ny Saml. VI 1792, p415ff.

6. For eksempel Phil. Mag. vol 8; Enc. Lond. vol 6, 1810; Edinburgh Enc. vol 8, 1830.

7. Annalen der Physik Bd. 66 p294. Omtalt i Kirstine Meyer H.C. Ørsted Naturvidenskabelige Skrifter Bind I pCIV.

8. Kataloget findes på Gammel Estrup, Jyllands Herregårdsmuseum, 8963 Auning. Jeg takker Museumsinspektør Vibeke Nielsen for at henlede min opmærksomhed på det.

9. Alison McCann: «A Private Laboratory at Petworth House, Sussex, in the Late Eighteenth Century» i Annals of Science 40, 6, November 1983, p 635-655.

10. C.R. Hill «The Cabinet of Bonnier de la Mosson (1702-1744)" i Annals of Science, 43 (1986) p147-174.

11. Note 2, p80ff.

12. J.A. Bennett The divided Circle, Phaidon Christies, 1987, p14.

13. Note 2, p208ff

14. Problemet er behandlet af Deborah Jean Warner: "What is a Scientific Instrument, when did it become one, and why?» i British Journal of the History of Science, 23, 1990, p83-93.

15. Mary Holbrook, med tilføjelser af R G W Anderson og D J Bryden Science Preserved, a directory of scientific instruments in collections in the United Kingdom and Eire London HMSO 1992.

16. Charles Mollan Irish National Inventory of
Historic Scientific Instruments. Interim Report. Royal Dublin Society, 1990.

17. Gerard L'E. Turner Nineteenth Century Scientific Instruments, Sotheby Publications 1983, p 18.

18. Note $14, \mathrm{p} 93$

19. Historic Scientific Instruments in Denmark er en registrant over ca 2500 instrumenter i museer, universiteter, skoler og private samlinger. Den udkommer formentlig i løbet af 1994 og er begyndelsen til en komplet registrant over danske scientiske instrumenter, som det er tanken at skabe i de kommende år som en database. Lignende projekter er gang $\mathrm{i}$ andre lande.

20. J A Bennett "Science Museums and Science Historys i An Apparatus of Instruments: The Role of the Scientific Instrument Comission, edited by R G W Anderson and G L'E Turner, London 1993.

21. Beskrivelsen af dette nye museum, der anses for toneangivende for videnskabshistoriske museer, er baseret på et foredrag holdt af Museumslederen, Peter de Clercq, i Conservatoire des Arts et Metiers, Paris, den 11 marts 1991. Foredraget er ikke udgivet.

22. Dette og et følgende citat er fra et foredrag People and Museums: Expectations and Responses holdt 17 november 1993 i Scientific Instrument Society i London. Foredraget er ikke udgivet.

Hemming Andersen er cand. polyt. 1949. Arbejde som ingenior 1949-1964 i Danmark, Canada, England og Vesttyskland. Lektor ved Soro Akademis Skole, matematik, fysik og kemi 1964-1992. Ansvarlig for opstillingen af Hauchs Samling $i$ "Vanget" på Soro Akademi 1976-1992. Projektarbejde: 'Historic Scientific Instruments in Denmark' 1990-1992. (Adr: Bymollevej 1, 5960 Marstal). 